\title{
Profil keloid di Poliklinik Kulit dan Kelamin RSUP Prof. Dr. R. D. Kandou Manado periode Januari 2011-Desember 2015
}

\author{
${ }^{1}$ Rina D. S. Andisi \\ ${ }^{2}$ Pieter L. Suling \\ ${ }^{2}$ Marlyn G. Kapantow \\ ${ }^{1}$ Kandidat Skripsi Fakultas Kedokteran Universitas Sam Ratulangi Manado \\ ${ }^{2}$ Bagian Ilmu Kesehatan Kulit dan Kelamin Fakultas Kedokteran \\ Universitas Sam Ratulangi Manado \\ Email: Rinadiyanti28@gmail.com
}

\begin{abstract}
Keloid is an abnormal scar that appears as an impact of wound healing process. Trauma, skin tension, hormone, and genetics are the risk factors of keloid. This study was aimed to obtain the profile of keloid patients at Polyclinic of Dermatology and Venereology Prof. Dr. R. D. Kandou Hospital in the period 2011-2015. This was a retrospective descriptive study using data of registration book and medical records. The results showed that the incidence of keloid in the period 2011-2015 was 93 cases (1.68\%). Based on gender, females were the most $(52.69 \%)$. The age group that had the highest in number was 15-24 years old (36.56\%). Based on occupation, most were students (25 cases; 26,88\%). The most common location of lesion was on the chest, which accounted for 48 cases $(51.61 \%)$. Eighty-nine cases (90.70\%) used intralesion steroid injection as the therapy. Conclusion: Keloid was more common in females, age group 15-24 years old, and occupation as students. The most common location of the lesion was on the chest, and the intraleson steroid injection was the most used therapy for keloid.
\end{abstract}

Keywords: keloids, scar, profile

\begin{abstract}
Abstrak: Keloid adalah parut abnormal yang timbul sebagai akibat dari proses penyembuhan luka. Trauma, ketegangan kulit, hormon, dan genetik merupakan faktor penyebab terbentuknya keloid. Penelitian ini bertujuan untuk mengetahui profil penderita keloid yang berobat di Poliklinik Kulit dan Kelamin RSUP Prof. Dr. R. D. Kandou Manado periode tahun 2011-2015. Jenis penelitian ialah deskriptif retrospektif menggunakan data dari buku register dan catatan rekam medik. Hasil penelitian menunjukkan insidensi penderita keloid periode 2011-2015 sebanyak 93 kasus (1,68\%). Distribusi kasus terbanyak pada perempuan (52,69\%), kelompok umur 15-24 tahun (36,56\%), pekerjaan sebagai pelajar dengan 25 kasus $(26,88 \%)$. Lokasi lesi paling sering pada daerah dada yaitu sebanyak 48 kasus $(51,61 \%)$. Sebanyak 89 kasus $(90,70 \%)$ menggunakan terapi injeksi steroid intralesi. Simpulan: Berdasarkan hasil penelitian ini keloid lebih sering pada perempuan, kelompok umur 15-24 tahun, pekerjaan sebagai pelajar, dengan lokasi lesi paling sering pada daerah dada dan injeksi steroid intralesi merupakan terapi keloid yang paling banyak digunakan.
\end{abstract}

Kata kunci: keloid, bekas luka, profil

Keloid adalah parut abnormal yang timbul sebagai akibat dari proses penyembuhan luka. Keloid terjadi karena sintesis dan penumpukan kolagen yang berlebihan dan tidak terkontrol pada kulit yang sebelumnya terjadi trauma dan mengalami penyembuhan luka. ${ }^{1}$ Jaringan ikat kolagen dihasilkan oleh sel fibroblas. Trauma, ketegangan kulit, hormon, dan genetik merupakan faktor penyebab terbentuknya 
keloid. $^{2}$ Keloid merupakan permasalahan yang sangat mengganggu jika timbul pada bagian wajah dan telinga. Hal tersebut dapat menimbulkan turunnya kepercayaan diri. Sifat keloid yang rekuren setelah pengobatan juga dapat menyebabkan masalah bagi penderita. ${ }^{3}$

Diagnosis keloid ditegakkan melalui gambaran klinis yaitu lesi yang timbul berupa nodul, awalnya berwarna pink sampai ungu dan terasa nyeri, gatal atau keduanya. Epidermis tampak halus dan bagian dermis dari lesi dapat diraba. ${ }^{4}$

Keloid timbul paling cepat satu sampai tiga bulan atau bisa lebih dari satu tahun setelah trauma atau faktor pencetus lainnya. Tumbuh melewati garis luka dan tidak mengalami regresi spontan dengan respon terhadap terapi yang rendah. ${ }^{5}$

Keloid sering terjadi pada usia antara 10-30 tahun. Setiap tahunnya di negara berkembang, terdapat 100 juta pasien dengan keluhan timbul jaringan parut di mana 55 juta diantaranya merupakan dampak dari pembedahan elektif dan 25 juta kasus lainnya merupakan hasil pembedahan dari kasus trauma. ${ }^{6}$ Angka kejadian keloid dilaporkan terjadi antara 4,5-16\% di mana $16 \%$ diantaranya terjadi pada ras kulit hitam Afrika. Insiden tertinggi keloid terjadi pada ras kulit hitam dan Hispanik. Angka kejadian keloid di Hawai, ditemukan 5 kali lebih banyak pada orang keturunan Jepang dan 3 kali lebih banyak pada orang keturunan Cina dari orang kulit putih (Polinesia). Di Indonesia, berdasarkan hasil penelitian observasional yang dilakukan di RS dr. Soetomo Surabaya, pada 30 kasus keloid, diperoleh data bahwa $76,7 \%$ penderita keloid terbanyak ialah perempuan pada umur 10-30 tahun. ${ }^{1}$

Penelitian tentang keloid pernah dilakukan di RSUP Prof. Dr. R. D. Kandou Manado pada Januari 2008 - Desember 2010 dengan jumlah pasien keloid sebanyak 61 pasien. Jumlah terbanyak pasien keloid terjadi pada tahun 2010 yaitu sebanyak 23 pasien. Berdasarkan jenis kelamin, perempuan lebih tinggi angka kejadiannya yaitu sebanyak $62,3 \%$ kasus dibandingkan laki-laki yang hanya sebanyak $37,7 \%$ kasus keloid.

Keloid memberikan keluhan yang mengganggu pada pasien dari segi kosmetik dan gejala klinis seperti rasa gatal dan sebagainya. ${ }^{6}$ Masalah penanggulangan keloid juga masih dipertanyakan karena keloid masih bersifat rekuren setelah diobati. ${ }^{2}$ Penelitian ini bertujuan untuk mendapatkan profil keloid di Poliklinik Kulit dan Kelamin RSUP Prof. Dr. R. D. Kandou Manado periode Januari 2011Desember 2015

\section{METODE PENELITIAN}

Jenis penelitian ini ialah deskriptif retrospektif menggunakan data subjek penelitian yang diambil dari buku register dan catatan rekam medik pasien keloid sepanjang tahun 2011 sampai dengan tahun 2015 di Poliklinik Kulit dan Kelamin RSUP Prof. Dr. R. D. Kandou Manado. Populasi ialah semua kasus baru yang tercatat di poliklinik kulit dan kelamin dan instalasi rekam medik RSUP Prof. Dr. R. D. Kandou Manado periode Januari 2011Desember 2015. Sampel ialah semua kasus baru yang didiagnosis klinis keloid di poliklinik kulit dan kelamin dan instalasi rekam medik RSUP Prof. Dr. R. D. Kandou Manado periode tahun 2011 sampai dengan tahun 2015.

\section{HASIL PENELITIAN}

Setelah melakukan penelitian secara retrospektif mengenai penderita keloid di Poliklinik Kulit dan Kelamin dan Instalasi Rekam Medik RSUP Prof. Dr. R. D. Kandou Manado periode tahun 2011 sampai dengan tahun 2015 maka diperoleh data sesuai variabel sebagai berikut:

Distribusi kasus keloid berdasarkan jumlah kasus periode Januari 2011Desember 2015 di Poliklinik Kulit dan Kelamin RSUP. Prof. Dr. Kandou Manado yaitu sebanyak 93 (1,68\%) kasus keloid dari total 5550 kasus penyakit kulit.

Pada Tabel 1 didapatkan persentase kasus terbanyak pada tahun 2015 yaitu sebanyak $2,60 \%$ dan terendah pada tahun 2011 sebanyak $0,45 \%$. 
Tabel 1. Distribusi kasus keloid menurut jumlah kasus kulit pertahun

\begin{tabular}{ccc}
\hline Tahun & $\begin{array}{c}\text { Jumlah } \\
\text { penderita } \\
\text { penyakit kulit } \\
(\mathbf{n})\end{array}$ & $\begin{array}{c}\text { Jumlah } \\
\text { penderita } \\
\text { keloid } \\
(\%)\end{array}$ \\
\hline 2011 & 881 & $4(0.45 \%)$ \\
2012 & 1096 & $17(1.55 \%)$ \\
2013 & 1457 & $26(1.78 \%)$ \\
2014 & 1232 & $23(1.87 \%)$ \\
2015 & 884 & $23(2.60 \%)$ \\
Total & 5550 & $93(1.68 \%)$ \\
\hline
\end{tabular}

Pada Tabel 2 dapat dilihat jumlah kasus keloid lebih banyak ditemui pada perempuan yaitu sebanyak 49 kasus $(52,69 \%)$ dibandingkan lak-laki yaitu sebanyak 44 kasus $(47,31 \%)$ dengan perbandingan $1,1: 1$.

Tabel 2. Distribusi kasus keloid menurut jenis kelamin

\begin{tabular}{ccc}
\hline Jenis kelamin & $\begin{array}{c}\text { Jumlah } \\
\text { penderita } \\
\text { (n) }\end{array}$ & $\boldsymbol{\%}$ \\
\hline Laki - Laki & 44 & 47.31 \\
Perempuan & 49 & 52.69 \\
Total & 93 & 100 \\
\hline
\end{tabular}

Dari Tabel 3 diperoleh kasus keloid terbanyak pada kelompok umur 15-24 tahun sebanyak 34 kasus $(36.56 \%)$ dan paling terendah pada kelompok 5-14 tahun sebanyak 2 kasus (2.15\%).

Tabel 3. Distribusi kasus keloid menurut umur

\begin{tabular}{c|cc}
\hline $\begin{array}{c}\text { Umur } \\
\text { (tahun) }\end{array}$ & $\begin{array}{c}\text { Jumlah pasien } \\
\text { (n) }\end{array}$ & \% \\
\hline$<1$ & - & - \\
$1-4$ & - & - \\
$5-14$ & 2 & 2,15 \\
$15-24$ & 34 & 36,56 \\
$25-44$ & 33 & 35,48 \\
$45-64$ & 19 & 20,43 \\
$\geq 65$ & 5 & 5,38 \\
TOTAL & 93 & 100 \\
\hline
\end{tabular}

Distribusi kasus keloid berdasarkan pekerjaan dari total pasien 93 kasus keloid paling banyak terjadi pada pasien dengan status pelajar baik SD hingga mahasiswa yaitu sebanyak 25 kasus (26.88\%). Terendah pada pasien dengan status petani dan wiraswasta masing-masing 3 kasus (3.23\%) dan 2 kasus (2.15\%).

Tabel 4. Distribusi kasus keloid menurut pekerjaan

\begin{tabular}{ccc}
\hline Pekerjaan & $\begin{array}{c}\text { Jumlah } \\
\text { Pasien } \\
\text { (n) }\end{array}$ & \% \\
\hline IRT & 23 & 24.73 \\
PNS & 7 & 7.53 \\
Swasta & 19 & 20.43 \\
Pelajar & 25 & 26.88 \\
Pensiunan & 7 & 7.53 \\
Wiraswasta & 2 & 2.15 \\
Petani & 3 & 3.23 \\
Tidak diketahui & 7 & 7.53 \\
Total & 93 & 100 \\
\hline
\end{tabular}

Keloid paling banyak ditemukan didaerah dada yaitu sebanyak 48 kasus $(51.61 \%)$ dan daerah terendah terkena keloid dengan jumlah sebanyak 2 kasus $(2.15 \%)$ yaitu pada daerah wajah dan leher

Tabel 5. Distribusi kasus keloid menurut lokasi lesi

\begin{tabular}{ccc}
\hline Lokasi Lesi & $\begin{array}{c}\text { Jumlah } \\
\text { Pasien } \\
\text { (n) }\end{array}$ & \% \\
\hline Wajah & 2 & 2,15 \\
Telinga & 4 & 4,30 \\
Leher & 2 & 2,15 \\
Dada & 48 & 51,61 \\
Perut & 5 & 5,38 \\
Punggung & 4 & 4,30 \\
Ekstremitas atas & 10 & 10,75 \\
Ekstremitas bawah & 5 & 5,38 \\
Kombinasi & 13 & 13,98 \\
Total & 93 & 100 \\
\hline
\end{tabular}

Distribusi kasus keloid berdasarkan terapi yang di berikan di RSUP Prof. Dr. R. D. Kandou Manado Periode Januari 2011 Desember 2015 dari total 93 kasus keloid yaitu terbanyak dengan 89 kasus $(95.70 \%)$ diberikan terapi injeksi steroid intralesi (triamcinolon acetonide) dan 4 kasus $(4.30 \%)$ dilakukan eksisi. 
Tabel 6. Distribusi kasus keloid menurut terapi

\begin{tabular}{ccc}
\hline Terapi & $\begin{array}{c}\text { Jumlah } \\
\text { Pasien } \\
(\mathbf{n})\end{array}$ & \% \\
\hline Injeksi steroid & 89 & $95.70 \%$ \\
Intralesi & & \\
Eksisi & 4 & $4.30 \%$ \\
Total & 93 & 100 \\
\hline
\end{tabular}

\section{BAHASAN}

Pada periode Januari 2011 - Desember 2015 di Poliklinik Kulit dan Kelamin RSUP. Prof. Dr. R. D. Kandou Manado ditemukan kasus keloid sebanyak 93 $(1,68 \%)$ kasus dari total 5550 kasus penyakit kulit di Poliklinik Kulit dan Kelamin RSUP Prof. Dr. R. D. Kandou Manado. Jumlah ini mengalami penurunan dibandingkan penelitian sebelumnya tentang profil keloid periode Januari 2008 Desember 2010 yang dilakukan di Poliklinik Kulit dan Kelamin RSUP Prof. Dr. R. D. Kandou Manado dengan jumlah kasus sebanyak 61 pasien keloid $(2.07 \%)$ dari 2945 total kasus penyakit kulit. ${ }^{7}$ Walaupun demikian perbandingan persentase jumlah kasus keloid antara penelitian sekarang dengan penelitian sebelumnya yang dilakukan di poliklinik Kulit dan Kelamin RSUP Prof. Dr. R. D. Kandou Manado tidak memberikan perbedaan yang mencolok.

Distribusi kasus keloid menurut jenis kelamin untuk penelitian di RSUP Prof. Dr. R. D. Kandou Manado periode Januari 2011 - Desember 2015 didapatkan jumlah kasus keloid terdiri dari 44 kasus $(47,31 \%)$ pada laki-laki dan 49 kasus $(52,69 \%)$ pada perempuan (Tabel 2) sehingga didapatkan perbandingan $1: 1,1$, dimana kasus keloid lebih banyak terjadi pada perempuan dibandingkan laki-laki. Walaupun pada penelitian ini angka kejadian keloid lebih banyak pada perempuan dibandingkan lakilaki, tetapi hasil tersebut tidak terlalu signifikan antara laki-laki dan perempuan. Hasil yang sama juga ditemukan pada penelitian sebelumnya tentang profil keloid periode Januari 2008-Desember 2010 yang dilakukan di poliklinik Kulit dan Kelamin RSUP Prof. Dr. R. D. Kandou Manado bahwa perempuan sebagai kasus terbanyak untuk distribusi kasus keloid berdasarkan jenis kelamin yaitu sebanyak 38 kasus $(62,30 \%)$ dibandingkan laki-laki yang hanya 23 kasus $(37,70 \%){ }^{7}$ Pada penelitian sebelumnya juga tidak jauh berbeda antara laki-laki dan perempuan. Hal ini sejalan dengan teori yang menyatakan bahwa kasus keloid lebih banyak ditemukan pada perempuan daripada laki-laki. ${ }^{6,8}$ Angka kejadian kasus keloid lebih banyak pada perempuan dibandingkan laki-laki mungkin dikarena-kan perempuan lebih merasa terganggu penampilannya akibat timbulnya keloid yang sering membesar melampaui batas luka asli sehingga cenderung memeriksa-kan diri ke dokter. ${ }^{9}$

Keloid dilihat dari distribusinya berdasarkan umur, didapatkan golongan umur terbanyak untuk kasus keloid ialah 15-24 tahun sebanyak 34 kasus $(36,56 \%)$ dan terendah pada umur 5-14 tahun yaitu sebanyak 2 kasus (2,15\%) (Tabel 3). Hasil yang sama juga terjadi pada penelitian tahun 2011 tentang profil keloid periode Januari 2008-Desember 2010 di RSUP. Prof. Dr. R. D. Kandou Manado didapatkan hasil terbanyak pada usia 15-24 tahun dengan 33 kasus $(54,10 \%){ }^{7}$ Hal ini sejalan dengan teori yang menyebutkan bahwa keloid biasa terjadi pada orang dengan usia yang lebih muda. ${ }^{10}$ Hal ini mungkin disebabkan usia muda merupakan usia yang rentan terkena trauma akibat banyaknya aktivitas yang dilakukan sehari-harinya. Selain hal tersebut, bekas jerawat akibat jerawat yang sering timbul pada usia tersebut dapat menjadi salah satu faktor resiko timbulnya keloid. ${ }^{11}$

Pada distribusi keloid berdasarkan pekerjaan didapatkan bahwa pelajar merupakan kasus terbanyak dengan 25 kasus $(26,88 \%)$ (Tabel 4). Hal ini sejalan dengan hasil sebelumnya pada penelitian ini bahwa kasus keloid banyak ditemukan pada golongan umur 15-24 tahun yang masih berstatus pelajar SMA dan mahasiswa. Selain itu, hasil pada penelitian ini juga sebanding dengan hasil penelitian yang pernah dilakukan sebelumnya tentang profil keloid periode Januari 2008- 
Desember 2010 di RSUP Prof. Dr. R. D. Kandou, dimana pelajar juga merupakan status terbanyak dengan 17 kasus $(27,87 \%)$. Pelajar merupakan usia pubertas yang memiliki kadar hormon androgen yang tinggi sehingga sering timbul jerawat. Jerawat dapat meninggalkan luka bekas jerawat yang mungkin menjadi salah satu faktor resiko timbulnya keloid., ${ }^{3,10}$ Selain itu, pelajar mungkin rentan terkena trauma saat beraktivitas sehingga hal tersebut bisa menjadi faktor resiko terjadinya keloid. Namun pada data yang diperoleh tidak dijelaskan secara rinci tentang apakah pekerjaan pasien tersebut beresiko tinggi terhadap terjadinya trauma. Status pekerjaan lainnya seperti PNS, swasta, dan wiraswasta juga tidak tercatat secara spesifik dalam rekam medik bagaimana kegiatan sehari-harinya, sehingga penulis sulit untuk mencari hubungan antara pekerjaan pasien dengan insiden terjadinya keloid.

Distribusi kasus keloid berdasarkan lokasi lesi timbulnya keloid didapatkan kasus terbanyak pada daerah dada yaitu sebanyak 48 kasus $(51,61 \%)$ (Tabel 5). Hasil penelitian tersebut tidak sejalan dengan teori yang mengatakan bahwa keloid sering timbul pada daerah telinga akibat tradisi tindik telinga yang dilakukan oleh kaum perempuan. ${ }^{6,8}$ Keloid sering timbul pada daerah dada mungkin dihubungkan dengan luka bekas jerawat pada dada yang mengalami proses penyembuhan luka yang kurang baik. Dada merupakan salah satu tempat tersering timbulnya jerawat dan daerah yang mempunyai ketegangan kulit yang tinggi. ${ }^{12}$

Jerawat akan meninggalkan luka bekas jerawat setelah pecah. ${ }^{3,10}$ Luka bekas jerawat pada daerah dada akan mengalami proses penyembuhan luka yang kurang baik karena daerah ini merupakan daerah ketegangan kulit yang tinggi. ${ }^{11}$

Jenis terapi untuk keloid yang dapat dijumpai pada penelitian ini yaitu untuk 89 kasus keloid dengan persentase 95,70\% ditangani dengan terapi injeksi steroid intralesi (Tabel 6). Kortikosteroid yang dipakai untuk terapi injeksi steroid intralesi di Poliklinik Kulit dan Kelamin RSUP. Prof. Dr. R. D. Kanadou Manado adalah triamcinolon acetonide. Injeksi steroid intralesi merupakan pengobatan andalan dalam menangani keloid. Menurut kepustakaan, triamcinolone acetonide diberikan dengan dosis $10-40 \quad \mathrm{mg} / \mathrm{ml}$ intralesi setiap 3-4 minggu. ${ }^{13}$ Penggunaan kortikosteroid memberikan efek penekanan pada proses inflamasi pada luka. ${ }^{14}$ Selain terapi tersebut, terapi lain yang dipakai untuk kasus keloid di Poliklinik Kulit dan Kelamin RSUP Prof. Dr. R. D. Kandou Manado yaitu terapi eksisi. Kasus keloid dengan terapi eksisi didapatkan sebanyak 4 kasus $(4,30 \%)$. Berdasarkan catatan rekam medik di RSUP Prof. Dr. R. D. Kandou Manado, terapi eksisi tidak dilakukan oleh dokter spesialis kulit dan kelamin tetapi dikonsultasikan dengan bagian bedah plastik untuk dilakukan terapi eksisi. Menurut kepustakaan, terapi eksisi dapat menimbulkan rekurensi yang lebih cepat. ${ }^{1}$ Hal tersebut mungkin menyebabkan terapi injeksi steroid intralesi lebih banyak dipakai dibandingkan terapi eksisi. Terapi eksisi lebih efektif dikombinasikan dengan terapi injeksi steroid intralesi atau bebat tekan setelah dilakukan eksisi. Hal tersebut dapat mengurangi rekurensi. ${ }^{13}$ Terapi keloid lainnya seperti krioterapi, laser, radioterapi, gel silikon, imiquimod topikal, dan terapi kompresi belum dilakukan di Poliklinik Kulit dan Kelamin RSUP Prof. Dr. R. D. Kandou Manado.

\section{SIMPULAN}

Dari hasil penelitian tentang profil keloid di Poliklinik Kulit dan Kelamin serta Instalasi Rekam Medik RSUP. Prof. Dr. R. D. Kandou Manado periode tahun 2011 sampai tahun 2015 dapat disimpulkan insidensi kasus keloid sebesar 1,68\%. Persentase tertinggi ditemukan pada jenis kelamin perempuan, kelompok umur 15-24 tahun, pekerjaan pelajar, dan lokasi lesi daerah dada. Terapi yang paling sering diberikan ialah terapi injeksi steroid intralesi. 
Andisi, Suling, Kapantow: Profil keloid di...

\section{SARAN}

1. Kelengkapan dalam pengisian status pasien sangat diperlukan guna menunjang pendataan yang lengkap, akurat dan informatif.

2. Pengumpulan data dan penyimpanan catatan rekam medik harus diperhatikan.

3. Perlu dilakukan penelitian lebih lanjut mengenai hubungan antara pekerjaan dan insidensi terjadinya keloid.

\section{DAFTAR PUSTAKA}

1. Goldsmith LA, Katz SI, Gilchrest BA, Paller SA, Leffel DJ, Wolf K editor. Fitzpatrick's Dermatology in General Medicine (8th ed). New York: McGraw-Hill, 2012; p. 708-10.

2. O"Toole EA, Mellerio JE. Wound healing. In: Burns $\mathrm{T}$, Breathnach S, Cox N, Griffiths C editors. Rook's Textbook of Dermatology (8th ed). UK: Wiley Blackwell, 2010; p.14.5.

3. Sukasah CL. Penggunaan silicone gel sheet pada keloid dan jaringan parut hipertropik. Maj Kedokt Indon. 2007;57(2):1-3.

4. Robins JK, Hanke CW, Siegel DM, Fratila A. Keloid. In: Berman B, Amini S, Baldwin H editors. Surgery of the Skin : Procedural Dermatology (3rd ed). Philadelphia: Saunders Elsevier, 2015; .p. 673-87.

5. Butler DP, Longaker TM, Yang PG. Current Progress in Keloid Research and Treatment. Elsevier Inc. 2008;206(4):731-41.

6. Pratiwi DK, Perdanakusuma D. Hubungan antara Golongan Darah dengan Timbulnya Keloid Pascaluka.
Surabaya: Airlangga University Press; 2009.

7. Oroh AG. Profil keloid di Poliklinik Kulit dan Kelamin RSUP Prof. Dr. R. D. Kandou Manado periode Januari 2008 - Desember 2010 [karya tulis ilmiah]. Manado: Fakultas Kedokteran Universitas Sam Ratulangi; 2011.

8. Kryger BZ. Hypertrophic scars and keloids. In: Kryger BZ, Sico $M$ editors. Practical Plastic Surgery. Georgetown: Landes Bioscience, 2007; p. 17-20.

9. Gawkrodger, David J, Michael R, Ardern J. Dermatology: An Illustrated Color Text (5th ed). Philadelpia: Elsevier; 2012; p. 95.

10. Nast A, Eming S, Fluhr J, et al. German S2k guidelines for the therapy of pathological scars (hypertrophic scars and keloids). J Dtsch Dermatol Ges. 2012;10(10):747-62.

11. Robins JK, Hanke CW, Siegel DM, Fratila A. Keloid. In: Berman B, Amini S, Baldwin H editors. Surgery of the Skin : Procedural Dermatology (3rd ed). Philadelphia: Saunders Elsevier, 2015; p. 673-87.

12. Ramdani R, Sibero HT. Treatment for acne vulgaris. J Majority. 2015;4(2): 87-95.

13. Cipto H, Suriadiredja A. Tumor kulit. In: Menaldi S, Bramono K, Indriatmi W, editors. Ilmu Penyakit Kulit dan Kelamin (7th ed). Jakarta: Badan Penerbit FKUI, 2015; p. 265.

14. Gerd G, Gauglitz. Management of keloids and hypertrophic scars: current and emerging option. Dove press open acces journals. 2013;6:103-14. 